\title{
1. Criminal justice: system, process and legitimacy
}

Alexander Hamilton, writing in the Federalist (No. 78), described the judiciary in a democracy as the weakest and least dangerous department of government. More than 200 years later I would argue that his statement accurately describes the role of the judiciary in the governance of our country.

(Lord Steyn, 1997)

At a general level, the highest courts in both England and Scotland have enjoyed an authoritative status over many centuries in the sense that they have secured a substantial measure of public confidence. They have not only attained de facto authority but, by providing considered and reflective judgments, have secured 'normative-justificatory' authority. ${ }^{1}$ They have, in short, offered persuasive reasons why people should respect their role as well as their individual rulings. In this process, courts have garnered public respect, deference and trust even though particular judgments have been controversial. In political science terms, this equates to having secured 'diffuse support', that is, loyalty to an institution which is not contingent upon satisfaction with the immediate outputs. ${ }^{2}$

Our concern in this book goes beyond the issue of public confidence and, instead, is with the question of the legitimacy of British courts by reference to their law-making or policy functions in the arena of criminal justice as seen through the lens of State-induced guilty pleas. State-induced guilty pleas, here, include all practices commonly referred to as 'plea bargaining' (a term we occasionally use in the same sense) to cover, for example, direct or indirect offers from State officials (police, prosecutors and judges) to reduce a sentence in return for a guilty plea, offers to reduce the number of charges or alter the charge(s) from a more serious to a less serious offence, or offers to present the 'facts' (the basis of the guilty plea) in a favourable light.

Courts seek to secure authority by anchoring their determinations in

1 Less tangible considerations such as exposure to the symbols and rituals of law no doubt contribute to public confidence.

2 Gibson (2006). 
terms of formal legal rationality directed by internally-generated principles and values which claim independence from other arms of government and 'political' influence. Key elements of the notion of formal legal rationality include protecting the right to a fair trial, ensuring the autonomy of the legal actors, providing individual, rather than aggregate, decision-making and, through reasoned judgments, holding law-makers and prosecutors to account by requiring that they justify their actions.

Legitimacy, however, cannot simply be tied to the formal claims of the prevailing legal order since, for various reasons including 'interpretive' decisions of the courts, formal legal rationality may not respect the rights of individuals. Legitimacy, accordingly, must have a moral basis which respects the basic rights of its citizens, such as the right to liberty and the right to privacy. Ronald Frey (1980) defines a moral right as 'a right which is not the product of community legislation or social practice, which prescribes the boundary beyond which neither individuals nor the community may go in pursuit of their overall ends'. Accordingly, our analysis of criminal justice goes beyond formal claims and interrogates the system's intrinsic rationale and its relationship with the moral rights of citizens.

\section{RIGHT TO A FAIR TRIAL}

A key moral basis of the adjudication of criminal disputes, the right to a fair trial, is set out in Article 6 of the European Convention on Human Rights (ECHR):

\section{ARTICLE 6}

1. In the determination of his civil rights and obligations or of any criminal charge against him, everyone is entitled to a fair and public hearing within a reasonable time by an independent and impartial tribunal established by law ...

2. Everyone charged with a criminal offence shall be presumed innocent until proved guilty according to law.

3. Everyone charged with a criminal offence has the following minimum rights:

(a) to be informed promptly, in a language which he understands and in detail, of the nature and cause of the accusation against him;

(b) to have adequate time and the facilities for the preparation of his defence;

(c) to defend himself in person or through legal assistance of his own choosing or, if he has not sufficient means to pay for legal assistance, to be given it free when the interests of justice so require;

(d) to examine or have examined witnesses against him and to obtain the attendance and examination of witnesses on his behalf under the same conditions as witnesses against him; 
(e) to have the free assistance of an interpreter if he cannot understand or speak the language used in court.

Underlying the right to trial is the understanding that infringement or curtailment of the moral rights of individual citizens (such as the right to liberty) ${ }^{3}$ must be justified by State officials to an authoritative and disinterested third party (an adjudicative tribunal) and to a high standard of proof. ${ }^{4}$ Trials, as Richard Lippke (2011) argues, produce a wide range of public and private goods, including: the promotion of accuracy; the affirmation of principles regarded as non-derogable (such as the prohibition against evidence produced by torture); the acquittal of innocent people; the exposure of incompetence, malfeasance or corruption on the part of State officials; the conviction of individuals proved to be factually and legally guilty by due process of law; the imposition of punishment at a level appropriate to the crime; the creation of a full record to provide a resource for checking for and rectifying error; and the reinforcement of basic norms of governance through their public demonstration. ${ }^{5}$

\section{ADVERSARY JUSTICE AND FORMAL LEGAL RATIONALITY}

In Britain, the concept of a fair trial is said to find its ideal expression in trial by jury. ${ }^{6}$ In $R v C C R C$ ex parte Pearson [2000] at 145, Lord Bingham summarised the protection it was said to afford:

It is essential to the health and proper functioning of a modern democracy that the citizen accused of crime should be fairly tried and adequately protected against the risk and consequences of wrongful conviction. To this end, police

\footnotetext{
3 See also, Feinberg (1992).

4 See Barbera, Messegue and Jabardo v Spain (1989). For a full discussion, see Lippke (2011).

5 See also, Albert Alschuler (1981) who argues that trials encourage genuine advocacy by defence lawyers thereby potentially exposing flaws and irregularities in the State's case that otherwise would be glossed over; restrain abuse of legislative or executive power by ensuring that the criminal law and its enforcement do not depart too widely from communal moral norms; and increase people's participation in their own governance and educate them in the importance of principles and rights.

6 The vast majority of court cases are disposed of in magistrates' courts. See, Carlen (1976) and McBarnet (1983) for a critical appraisal. Many criminal infractions are increasingly dealt with out of court as police and prosecutors seek to meet targets imposed on them (see further Chapters 5 and 8 ).
} 
operations to investigate crime and interrogate suspects are closely controlled by statutes, codes and rules; the conduct of prosecutions is entrusted to an independent, professional prosecuting authority; and legal aid is made available to fund all but the very well-to-do to defend themselves in serious cases. The main protection of the citizen accused of serious crime is, however, to be found in our system of trial by judge and jury ... [T] he procedure is adversarial . . . It is the function of the judge to direct the jury on the relevant law and to summarise (perhaps very briefly) the evidence, and to define the issues raised by the prosecution and the defence, including any possible defence disclosed by the evidence even if not relied on by the defendant. The judge need not, and should not, go further. Secondly, the decision on the defendant's guilt is made following a trial, continuous from day to day, by a jury assembled only for that trial, with no responsibility for the proceedings before the trial begins or after it ends.

Embedded in this is the general principle that the 'freedom of the individual must not be overridden by claims advanced on behalf of the State'. ${ }^{7}$ The evidential and procedural rules of the adversary system flow from a particular conception of social organisation in which many of the interests and moral rights of the individual are separated from the interests of the State. ${ }^{8}$ The primary interest to be protected is that of the individual. It is the defendant who is accorded fundamental rights. Each citizen has a right to personal autonomy and should be respected as an individual, not viewed as a resource; nor should the rights of any individual be subjugated to the interests of the collective in, for example, cost-effective case processing.

In this understanding, the State is not presumed to be beneficent and non-threatening but, rather, is seen as a potentially intrusive force. Nowhere is this intrusive potential more dramatised than in criminal justice where, by the very act of prosecution, the State is claiming the right to stigmatise and punish one of its citizens. One of the principal rights individuals have in this setting is the right not to be criminalised and punished for crimes they did not commit.

Because the State is claiming the right to punish one of its citizens, the State is required to justify its claim and every associated act of interference such as stops, search of the person and property, detention, arrest, taking intimate samples, telephone tapping, electronic surveillance and charge. Arising directly from this is the presumption of innocence. The State bears the burden of proof and must justify its every act through the

7 Royal Commission on Police Powers and Procedure (1929) Report, p. 10, para. 25. See also, Lord Justice Aikens in Regina v Anthony Pearce, Andrew Daniel William Galloway [2013].

8 Of course, it is also accepted that many of the interests of the State, such as in providing for an orderly and safe environment, are also in the interest of citizens. 
introduction of legally sufficient and admissible evidence without the compelled assistance of the accused person. In other words, the State cannot convict defendants and inflict punishment on them without proving that they committed each and every element of the offence charged, no matter how inconsequential any component of that offence might at first appear. Defendants in turn, do not have to do anything by way of producing evidence, but can, if they choose, rest the defence upon the failure of the State to discharge its burden of proof.

In discharging the requirement that it justify its claim regarding punishment of a citizen the burden shouldered by the State is high: unlike civil cases in which the claimant has to prove his or her case on a balance of probabilities, in a criminal case the State must discharge its burden of proof beyond reasonable doubt. An accused person is entitled to be acquitted if there is, from whatever source, reasonable doubt that the prosecution has established its case.

In its ideal form, therefore, judges have made clear that the criminal justice system is deliberately designed to guard against the possibility that factually guilty people might be found guilty on anything other than legally sufficient evidence and according to legally correct procedures. This not only means that the system gives formal recognition to "process values' but also that occasionally factually guilty defendants may be acquitted simply because the State is unable to discharge the burden of proof. While some may regard this possibility as providing inadequate protection of victims or other citizens who might become future victims of crime, the distinction between factual guilt and legal guilt is at the very heart of the adversary system.

There is a deeply moral dimension to this framework. As Ronald Dworkin (1985) points out, antecedent decisions taken by society may show special concern for moral harm, not only by paying a high price for accuracy but also and especially by paying a high price in accuracy to guard against a mistake that involves greater moral harm than a mistake in the other direction:

This is shown, for example, by the rule that guilt must be shown beyond reasonable doubt, rather than on a balance of probabilities, and also by rules, like the rule that an accused may not be compelled to testify, whose complex justification includes weighing the scales in favor of the accused, at the cost of accuracy, as well as guarding the accused against certain kinds of mistakes and misimpressions that might compromise accuracy. (p. 89)

To use Dworkin's terminology, the framework of rules in criminal cases has been said to rest on the basis that individuals have: (i) a right that criminal procedures attach the correct importance to the risk of moral 
harm; and (ii) the related and practically more important right to equal treatment with respect to that evaluation. Both are strong rights: that is, they trump the balance of bare gains and losses that form a standard utilitarian calculation. ${ }^{9}$

In traditional expressions of formal legal rationality by courts, the principles and values underlying this model infuse every segment of the system. The basis of the adversary system ${ }^{10}$ is party autonomy, with the trial judge (unlike his or her inquisitorial counterpart) ${ }^{11}$ acting as an umpire who leaves the preparation and presentation of the case to the prosecution and defence. Every case is given a unique identity. Every suspect and defendant is accorded personal autonomy and granted the right to be legally represented. Trials are to be held as public events in order to require State officials (who are not disinterested parties) to demonstrate that the justice system is working, thereby giving confidence to governance values; to prevent the suppression of incompetent or wrongful behaviour by State officials; to check State power; and to open up to argument important or contentious governance issues (see Lippke, 2011).

Under the pressure of 'abnormal' conditions, however, courts may not hold to the formal legal rules that they ordinarily proclaim. In such circumstances, where fractures appear in the ideal model, judges are forced to make at least temporary adjustments to claims regarding formal legal rationality in order to justify departures. Below, we explore some examples where this has been necessitated and the implications for the ideal model ordinarily advanced by judges.

\section{'ABNORMAL' SITUATIONS AND SYSTEM DEPARTURE}

The legitimacy of criminal courts, as legal institutions, has to be considered within their over-arching role as an essential component of the State's

\footnotetext{
9 Meaning, in this context, decisions based purely upon cost-efficient considerations. See further, Guest (2009).

10 In successive reviews of the criminal justice system of England and Wales, official inquiries have supported the continuation of the adversary system, as for example the Royal Commission on Criminal Procedure (1981) Report Cmnd 8092; and Royal Commission on Criminal Justice (1993) Report Cm 2263.

11 In reality, judges in civilian systems may be far from neutral arbiters in search of the truth. Hodgson $(2005,2006)$ shows that, for example, in the French system, much of the investigative power is delegated to the police who would not appear to be subject to any real supervision by investigating magistrates.
} 
social control apparatus, ${ }^{12}$ with a duty to uphold the law and without (it is claimed) any power to set it aside to avert injustice or other undesired outcomes. In this setting, their overall task has been described by Isaac Balbus (1973) as being threefold: to maintain public order; achieve formal legal rationality; and perpetuate the organisation. ${ }^{13}$ Striking a balance between these functions - which are often in conflict - is the work of courtroom actors. ${ }^{14}$ In this understanding, at times of social and political stability the values that should predominate are tested through adversary debate, but when there is serious political or social disruption (actual, manufactured or perceived), the discourse around values may recede, at least temporarily, and the reality of power - the repressive nature of the State - may prevail. ${ }^{15}$

Thus, Balbus found, in examining the response of the courts to the disorders and revolts in US black ghettos in the 1960s, that court procedures were altered, normal operating routines were changed, often contrary to procedural 'safeguards' and that whereas under more 'normal' conditions the impact of local political structure variations on policy outcomes was considerable, under crisis conditions their impact was virtually nil. Balbus saw this as explained by the self-contradictory interests of the judicial authorities: on the one hand, upholding legal-rational norms - 'formal legal rationality' in this context being 'the rule of law', 'due process of law', 'civil liberties' (equal treatment before the law), judicial decisions being made autonomously (insulated from the political sphere); on the other, their political interest in maintaining public order (ending the revolts) and the interest in organisational maintenance (in preventing the courts being overwhelmed by the inflow of cases).

Certainly, on one reading, the explanatory model proposed by Balbus appears to have similarities with the response of British courts in 'crisis' (real or manufactured) situations. We explore this question with three examples: Operation Major in 1982; the miners' strike in the 1980s; and the urban disorders in major cities in 2011.

12 Of course, the State responds in many ways, other than through the criminal process, in addressing the issue of crime, including education, environmental design, help and support agencies and deterrence mechanisms.

13 Balbus later explained that while the interests in formal rationality and organisational maintenance are permanent interests of the State, the interest in order (restoring order) does not have the same permanent status (1973; Preface to the 1977 edition).

14 Sheskin (1981).

15 Boyle et al. (1975). 


\section{Operation Major}

Many cities in the United Kingdom suffer from a shortage of housing accommodation ${ }^{16}$ and this can bear heavily upon single homeless people. ${ }^{17}$ Oxford was one such place in the 1980s. The relevant government office, the Department of Health and Social Security (DHSS), provided support to homeless people who stayed in bed and breakfast boarding houses run by landlords who received payment by the DHSS. Some boarding houses were said to be overcrowded, dirty and unhygienic such that some claimants chose to sleep in parks whilst continuing to use the property as an 'accommodation address' so that they could continue to claim benefit at a higher rate than they would otherwise be entitled to if sleeping rough. Such 'over-claiming' amounted to fraud. For their part, landlords would continue to be paid by the DHSS for all registered claimants. In some instances, the numbers of claimants allegedly using one 'accommodation address' rose towards 200 (Sandham, 1983). Claims made by landlords in respect of non-residents were clearly fraudulent and the potential fraud was alleged to be on a large-scale, far outweighing the small additional sums claimants were receiving.

In 1982, the Thames Valley Police, in conjunction with the DHSS, decided to mount a crackdown, 'Operation Major', against claimants only, not against landlords (Franey, 1983). Claimants reporting to their normal DHSS Benefit Office were sent a notice re-directing them to a fake office set up as part of Operation Major. The following week, claimants signed on at the 'office' as directed and had their claims processed. The police meanwhile arranged for noisy road-works immediately adjacent to the 'office', set up video cameras, conducted a 'rehearsal' with DHSS officers and liaised with the government to free up accommodation at the local prison.

When claimants came to register they were told by 'workmen' (undercover operatives) that they had to leave by another door. On leaving they were immediately detained and arrested by police officers. Those inside the fake office who sought to alert people who had not yet entered could not because of the noisy 'road-works'.

16 Because 'homelessness' is recorded differently, there is no national statistic for homelessness. However, in 2012/13, over 53,000 households were accepted as 'homeless' by the government in England; almost 6,500 in Wales; and over 34,000 in Scotland. See CRISIS at http://www.crisis.org.uk/pages/homeless-def-numbers. html. See also Rogers (2012).

17 If a person does not have dependent children (known as 'single homelessness') and the person is not deemed to be more vulnerable than other homeless people, the individual will probably not be entitled to housing. 
For some, the basis for an arrest was not the legal requirement of 'reasonable suspicion' but mere attendance, with arrestees including individuals who had simply accompanied those signing on. Most of those arrested were not told of their right to legal representation although some were. Social workers were not advised of what was happening although a number of those detained clearly needed such assistance. Those arrested were required to be photographed and fingerprinted.

Five Special Magistrates' Courts, depicted as 'emergency courts' (but secretly planned long in advance) were established to process those arrested. These 'daytime' courts, unusually sat from 15:00 hours to 23:00 hours, the ten magistrates themselves being previously unaware of the details of the operation. It was reported that the courts were constituted by individuals who could be relied upon to co-operate. ${ }^{18}$

Alongside this volume-operation, normal court procedures were set aside. Neither defence lawyers nor probation officers were given prior notice of these proceedings. As the day progressed and some solicitors became aware of what was happening, their attempts to gain access to the cells were refused by the police.

A large majority of those arrested $(88 \%)$ were not provided legal representation. Most court 'hearings' (lasting about four minutes each) were described as 'shelling' exercises in which claimants were processed as quickly as possible, the court clerk reading out the charge, the prosecution applying for a remand in custody and magistrates granting the request. Defendants were not required to enter pleas to specific charges; they were remanded on 'offences of obtaining property by deception'. Although there was in law a presumption in favour of bail, ${ }^{19}$ exceptionally, the vast majority $(91 \%)$ were remanded in custody with only a few $(9 \%)$ granted bail. $^{20}$

In the weeks that followed, the courts were prepared to deal substantively with the cases of those remanded in custody. In this initial period, most were State-induced guilty pleas entered under pressure of the process to which they had been subjected, many without the benefit of legal advice and some,

18 While magistrates' courts are overwhelmingly constituted by middle-aged lay personnel drawn from the middle classes with an unquestioning respect for and trust in authority (Burney, 1979; King and May, 1985; Dignan and Whynne, 1997), it is reported that they contained sufficient numbers of lower and working class members to call their reliability into question thus leading to further sieving, filtering and sifting.

19 Under the Bail Act, 1976.

20 A further eight had already been granted police bail. 
to get it over with, ${ }^{21}$ against the advice of their solicitors. Of the cases dealt with in the first month (158), the vast majority (88\%) pleaded guilty.

Sentencing followed a privately set tariff ${ }^{22}$ which, because it did not address the circumstances of individuals (such as differentiating between first offenders and those with a prior criminal record), amounted to aggregate punishment. Of those whose sentences are known, almost all (98\%), received immediate custodial sentences, ${ }^{23}$ a much higher proportion than usual for such offences. Indeed, the normal practice of the DHSS had been to not institute a prosecution at all where the overpayment involved was less than $£ 50$, which would have applied to all those convicted of a single offence.

However, and significantly, of the not guilty pleas (19), most (68\%) had their cases dismissed. Those defendants were now represented by lawyers who were able to demolish the evidence of the prosecution's principal witnesses, the two landlords of the bed and breakfast dwellings. Indeed, it emerged that the pro-forma evidence of one of the landlords had been written by a police officer and sent to the landlord afterwards for signature. It became clear that, had more claimants gone to trial instead of succumbing to State-inducements, their cases would also have been dismissed.

While at first blush the proceedings might appear to fit with the theory of Balbus - that formal legal rationality may be set aside at times of social 'crisis' - Balbus held an idealised view of legal rationality and underestimated the flexible, even friable, character of the 'law'. Indeed, setting aside the accurate observation that adherence to legality has been little more than symbolic in magistrates' courts, ${ }^{24}$ some elements of what was done under Operation Major fit readily into the existing legal architecture. ${ }^{25}$ Thus, the decision to focus on the homeless ${ }^{26}$ as opposed to landlords was within the law, ${ }^{27}$ the decision to charge under the Theft Act rather

21 See, Malcolm Feeley (1979) whose study of lower courts in America showed that the primary interest of most defendants was to get out of the system as quickly as possible, even if that meant pleading guilty.

22 The tariff was 30 days' imprisonment for each cheque fraudulently claimed with a further 15 days for any offences taken into consideration.

23 Two defendants were given suspended sentences. Of those remanded (47) to be dealt with later, most $(68 \%)$ were remanded in custody, only 15 being granted bail.

See Bridges (1975) reviewing Balbus (1973).

See in this context, McBarnet (1983) and McConville et al. (1991).

26 Press treatment of welfare claimants is usually derogatory. See, Golding and Middleton (1982) and Roche (1992).

27 Tax fraud costs the Treasury at least 15 times as much as is lost by welfare fraud (Hyde, 2010). Official 'crackdowns' on tax evasion often target minnows 
than under DHSS legislation was lawful; ${ }^{28}$ 'special courts', though heavily criticised in many quarters, are not illegal in the UK; ${ }^{29}$ and under the Bail Act courts retained a discretion to refuse bail because, for example, of a concern that the defendant would fail to surrender to custody, a reason that could easily be invoked in respect of homeless people.

Nevertheless, much about the whole procedure departs from the rational legal model espoused by the courts and violates basic moral precepts. The involvement of the police derived less from the character of the fraud and more from a desperate desire to restore the reputation of the Thames Valley Police whose image had been badly damaged in television documentaries earlier that year. ${ }^{30}$ Instead of the legal requirement of 'reasonable suspicion', the basis of arrests was simply 'being there' which resulted in claimants and non-claimants alike being detained and their moral rights (the right to liberty) impugned. Even making allowance for the fact that magistrates' courts are renowned for being prosecution-oriented, legitimacy was sacrificed: claimants were not accorded individual treatment, were denied access to lawyers and to bail, detained in purposely boarded up rooms and 'shelled' before specially selected magistrates uncritically applying a pre-set sentencing tariff in proceedings that would be dignified by the appellation 'hearings'.

Courts did not, however, seek to secure legitimacy for their actions

rather than large corporations: see, King (2011) reporting an increase in official prosecutions for tax evasion from 107 in 2010 to 148 in 2011, with the figures revealing that 'five taxpayers arrested last week [were] all believed to be plumbers'. The figure for tax avoidance (exploiting 'loopholes' in taxation provisions to minimise or extinguish tax liability) is, of course, exponentially much higher (the HMRC official estimate of 'lost revenue' for 2011/12 of $£ 35$ billion is regarded as the 'tip of the iceberg' by the Chair of the Parliamentary Public Accounts Committee: Syal, 2013). See also, Gee and Button (2013).

28 Franey (1983) discloses that Theft Act prosecutions were often used in other parts of the country where the defendant was a homeless person (at p.39). Indeed, as part of a new government campaign against benefit cheats, in September 2013 the Director of Public Prosecutions issued guidelines under which prosecutors are urged to charge under the Fraud Act rather than social security laws, thereby classifying welfare cheating alongside money laundering and banking fraud and exposing individuals to up to ten-year jail terms (in 2012, 262 offenders were jailed for benefit fraud, the average sentence being six months and one week).

29 In some jurisdictions the use of 'special courts' in this way is forbidden. Thus, for example, the Basic Law for the Federal Republic of Germany provides in Article 101(1): 'Extraordinary courts shall not be allowed. No one may be removed from the jurisdiction of his lawful judge'.

30 The documentaries being Roger Graef's series, The Police (BBC 1982) and Operation Carter (BBC 1982). 
through reliance upon formal legal rationality. Instead, the whole exercise rested on a race to the 'moral bottom': the representation that dispositive decisions were taken in respect of 'scroungers' and 'cheats', the undeserving of society. ${ }^{31}$ The denigration of claimants in a 'massive fraud' served to discredit the welfare system and reproduced spurious police claims about the amounts involved (the actual total over-claiming being estimated at less than $£ 50,000$, the police costs alone exceeding this by more than threefold) and the character of those being 'processed'. Although lawyers, social services and probation workers had been kept in the dark, the police action was immediately preceded by a covert stage-managed police briefing of the media. An obedient press ${ }^{32}$ characterised impending arrests as 'The Sting', ${ }^{33}$ set up to break a massive fraud racket:

Daily Star: THE STING: Police yesterday mounted a Sting-style operation to smash a massive social security racket.

Daily Express: THE STING: $£ 1.5 \mathrm{~m}$ fiddle smashed as 286 are held in bogus social security offices.

The police were lauded for their ingenuity in deceiving claimants, variously described as 'fiddlers', 'cheats' and 'swindlers', coupled with insinuations of spurious racist connections. ${ }^{34}$ The alliance of police, courts and a compliant press $^{35}$ thus sought legitimacy without recourse to the prevailing legal regime which was side-lined and wholly symbolic. Criminalisation and degradation of claimants was used to 'justify' 'aggregate justice', deflect attention from abnormal procedures and divert criticism from the lack of moral engagement with the problem of homelessness in society.

31 In fact, while overpayments due to fraud comprised $0.7 \%$ of total welfare expenditure in $2012 / 13$ ( $£ 1.2 \mathrm{bn}$ of $£ 166.8 \mathrm{bn}$ ), a further $0.9 \%$ ( $£ 1.5 \mathrm{bn}$ ) was overpaid because of claimant error and an additional $0.5 \%(£ 830 \mathrm{~m})$ because of errors by officials: 'Welfare fraud and error: how much is the UK losing?' Guardian, 13 May 2013.

32 News media were carefully selected beforehand with the less-obedient not informed.

33 Thereby likening the police operation to the film, The Sting.

34 Sun newspaper, for example, published a cartoon which showed 12 'scroungers' on a conveyor belt in front of magistrates, four of whom were black. In reality, of the 283 arrested, only four were people of colour, only one of whom was actually convicted.

35 Police relationships with the media have the potential not only for distorting public perceptions but also for involving the police in corrupt activity amounting to misconduct in public office. See, for example; BBC News, 23 January 2013, 'Police corruption: criminals "give officers steroids" BBC News, 26 April 2013, 'Former police officer admits selling stories to Sun' 26 April 2013. See further, Chibnall (1977), Howitt (1998), Leishman and Mason (2003) and Hohl (2011). 


\section{Miners' Strike}

The miners' strike in 1984 had many of the same characteristics as displayed in Operation Major. The strike was triggered by threatened pit closures on a huge scale by the Conservative Government led by Margaret Thatcher ${ }^{36}$ with the intention of closing pits and breaking the labour union, the National Mineworkers Union. With proposed massive job losses and the consequent destruction of many communities, miners sought to protect mines from closure and prevent coal from being transported by establishing picket lines and blockades at key pits.

Whatever was to happen in terms of policing or court processes, the question of 'legitimacy' in these respects was never to be settled by recourse to formal legal rationality. Long in advance of and during the strike, miners, together with their leader, Arthur Scargill, had been demonised by influential sections of the media. Incitive headlines such as 'Godfather Scargill's Mafia Mob' (News of the World, 7 October 1984) and 'Scargill's Real Aim is War' (The Sun, 5 April 1984) were accompanied by vitriolic attacks on the miners. ${ }^{37}$ As Williams (2009, p. 38) noted: 'Readers were left with a view that the strike was precipitated by the power-crazed antics of Arthur Scargill, and that extreme measures taken by the police at the pit gates and in the courts were caused solely by picket-line violence'.

Miners from other parts of the country were prevented from joining the picket by police road blocks sometimes set up 200 miles from the intended destination. This 'intercept policy' was purportedly based in the common law power available where police reasonably believe that a breach of the peace will be committed 'in the immediate future by the person arrested' (emphasis added) even though that person has not yet committed any breach. ${ }^{38}$ The police were also able to use section 5 of the Public Order

\footnotetext{
36 See, Fine and Millar (1985), Scraton (1985), Smith and Thomas (1985), Christian (1985) and Green (1990).

37 Arthur Scargill's claim, which underlay the concern of miners, that Margaret Thatcher had a 'secret hit-list' of more than seventy coal pits marked for closure, though officially denied at the time, has since gained support from newly released cabinet papers recording details of a secret meeting in 1984 (attended by a small group which included the Prime Minister and the Chairman of the National Coal Board) at which a plan to close a further 75 pits was unveiled: Higham (2014).

$38 \quad R v$ Howell (1981). The Divisional Court dismissed an appeal against the intercept policy, ruling that: 'The situation has to be assessed by the senior police officers present. Provided they honestly and reasonably form the opinion that there is a real risk of a breach of the peace in the sense that it is in close proximity both in place and time then the conditions exist for reasonable preventative action including, if necessary, the measures taken in this case. The possibility of a breach
} 
Act 1936 which allowed a police officer to intervene 'when a breach of the peace occurs or is imminent' (emphasis added). Police actions in the setting of road blocks and 'snatch squad' arrests were based on classifying the gathering of miners as involving 'public order' rather than an 'employment or industrial dispute'. ${ }^{39}$

Prosecuting strategies were devised to further undermine the strike. Arcane offences such as 'watching and besetting' ${ }^{40}$ were resurrected to counteract difficulties that the prosecution would otherwise have met in producing individual proof of specific abusive words or intimidatory behaviour. ${ }^{41}$ In Nottinghamshire, the police were allowed to by-pass the prosecuting solicitor altogether so that they could present cases directly to court and avoid questions relating to 'reasonable cause' and appropriateness of the charge. Defendants were almost all subject to a standard bail condition ${ }^{42}$ that had been attached to the bail sheets before the justices announced their decision. By a synthetic interpretation of the 'law', the Divisional Court held that this practice did not vitiate the decisions: while putting into the dock together defendants who had been arrested on different occasions or at different places was to be 'discouraged' as it made it difficult to avoid the appearance of 'group justice', and while it did the magistrates 'no credit' if standard conditions were affixed to bail forms even while applications were being made for unconditional bail, the fact that 'the outcome of the bail application was correctly anticipated did not mean that the justices were not exercising their discretion properly' ( $R v$ Mansfield Justices [1985]). In this 'creative' way the courts 'legalised' what clearly was 'group justice' and 'pre-determined decisions' and thereby avoided engagement with the political strategy the government was using, as outlined by Janie Percy-Smith and Paddy Hillyard (1985):

The aim of these practices was clearly containment, in the sense of preventing miners from taking any further part in picketing, rather than the prosecution and conviction of those committing criminal acts. There can be little doubt that

must be real to justify any preventative action. The imminence or immediacy of the threat to the peace determines what action is reasonable.' Moss v McLachlan, The Times, 29 November, 1984.

39 See, East and Thomas (1985).

40 Under the Conspiracy and Protection of Property Act, 1875.

41 Christian (1985).

42 In each case a condition was imposed in the following terms: 'Not to visit any premises or place for the purpose of picketing or demonstrating in connection with the current trade dispute between the N.U.M. and the N.C.B. other than peacefully to picket or demonstrate at his usual place of employment.' 
the policy of using this wide range of coercive powers rather than the powers in the new employment legislation was part of a coordinated and deliberate strategy. It criminalized those involved and discredited the miners' case in the eyes of the public and other trade unionists by casting them in the role of criminals or violent demonstrators rather than workers engaged in a legitimate industrial dispute. (p. 354)

Police 'snatch squads' were used to effect mass arrests of individuals, many of whom were simply engaged in lawful picketing, and these individuals were charged under section 5 of the Public Order Act 1936 which provided inter alia that: 'Any person who in any public place . . . uses threatening, abusive or insulting words or behaviour ... whereby a breach of the peace is likely to be occasioned, shall be guilty of an offence'. This provision enabled prosecutions to proceed based entirely upon police evidence. In these circumstances, and given that the magistrates were predisposed to view all picketing as actually involving or likely to occasion a breach of the peace (a view extraordinarily supported by the higher courts), ${ }^{43}$ many miners succumbed to State-induced guilty pleas in order to avoid jail, often acting on legal advice. ${ }^{44}$ As in Operation Major, had miners not succumbed to State inducements, the outcomes might have been very different, as the Orgreave trial showed.

The defining clash in the strike took place at Orgreave, a coking plant near Rotherham which the miners attempted to blockade. This descended into mass violence after the police on horseback charged the miners and attacked them with truncheons. A subsequent trial involved 15 miners charged with riot (the punishment for which could be up to life imprisonment); with more than eighty others awaiting trial. According to the prosecution, the miners, armed with implements such as an axe, ball

43 The argument that picketing was in any sense peaceful was summarily dismissed by magistrates, who, in turn, were supported by the Divisional Court. In $R v$ Mansfield Justices [1985] the Divisional Court, ruled that it must have been clear to everyone, including the justices that 'any suggestion of peaceful picketing was a colourable pretence and that it was a question of picketing by intimidation and threat. It must have been obvious to all those participating in the picketing that their presence in large numbers was part of the intimidation and threats. It must have been clear to them that their presence would, at the least, encourage others to threats and/or violence even if they themselves said nothing.' This finding, described accurately as 'devastating' (Christian, 1985, p. 129), meant in consequence that any miner involved in a picket was thereby guilty of an offence under section 5 .

44 See, for example, Ian Lavery, MP: 'Solicitors were telling them that if they accepted a public order offence they would avoid going to gaol', cited in Townsend (2012). An investigation is under way by the IPCC. 
bearings and metal bars charged at police lines ${ }^{45}$ 'hurling missiles in a quite terrifying display of violence which lasted several hours .... As the trial proceeded, however, it became clear that police statements were unreliable and had in many cases been dictated to them by senior officers. The signature of one officer may have been forged (the statement 'disappeared' during a lunch interval). After 48 days, the police evidence fell apart and the prosecution 'caved in' ${ }^{46}$ Michael Mansfield QC, who defended three of the acquitted miners, described South Yorkshire police's evidence then as 'the biggest frame-up ever', adding that, 'South Yorkshire police operated a culture of fabricating evidence with impunity, which was not reformed after Orgreave, and allowed to continue to Hillsborough five years later' ${ }^{47}$ Subsequently, examination of police statements by Mark George QC has revealed 'several dozen' examples of officers using exactly the same phrases, signifying 'widespread collusion'. ${ }^{48}$ According to Mr George: 'You can't get statements in the way they have been done here - by police officers from different forces involved in different arrests and find such a degree of similarity between those statements without there being some degree of collusion'.

\section{Urban Disorders, August 2011}

Between the 6th and the 10th of August 2011, England experienced some of the most extensive street disorders in its history, recalling the disturbances of three decades earlier in 1981 in Brixton, London, Moss Side in Manchester and Toxteth in Liverpool. The fatal shooting of Mark Duggan on Thursday 4 August 2011 by a police officer (code name V53) ${ }^{49}$ in Tottenham, London precipitated public protest in the area, which later sparked massive public disorder in London and other large cities such as Manchester, Liverpool and Birmingham. ${ }^{50}$ During this period, five people

45 A BBC film transposed events and showed miners initiating the attack by throwing stones at the police rather than, as happened, the other way round. It was not until 1991 that the BBC issued an apology in which it said that the film had been 'inadvertently transposed'.

46 Mansfield (2009).

47 Conn (2012).

48 BBC News, 22 October 2012.

49 In the 15 years to September 2010, 55 officers have opened fire on and killed 33 members of the public in England and Wales. In only two cases have the names of the officers been released (Leake et al., 2010).

50 It is noteworthy that fatal shootings by the police, even where the shooting was mistaken or unlawful, do not generally lead to civil disorder, which might suggest, where this occurs, a clear link with police-community relations. 
died. Significant looting, burglary, arson, violence against the police and criminal damage was widely experienced, with close to 15,000 people actively involved..$^{51}$ The response of the courts was swift: by August 2012, some 2,138 people had been convicted and sentenced. ${ }^{52}$

Long-standing community grievance (fuelled by ambiguity over the circumstances of Mark Duggan's death) ${ }^{53}$ was cited as a spark for the initial disorders which ignited two days after the shooting. ${ }^{54}$ While the full extent of the disorders and the possible causes have been documented elsewhere ${ }^{55}$ our interest here is with the legal aftermath. Nonetheless, the relationship between 'causes' and 'outcomes' remains vital to understanding the draconian attitude adopted by judges towards riot-related defendants.

Initially, the Justice Secretary, 'on-watch' during the disorders, was quick to rationalise events away from government austerity measures, deep frustration and community anger over police practices (including a massive use of stop and search powers disproportionately directed against members of the black and Asian community) ${ }^{56}$ and more generally a loss

\footnotetext{
51 Singh et al. (2012).

52 Ibid.
}

53 See Chapter 2. Ambiguities continued thereafter. Thus, at the inquest into the death of Mark Duggan, a police officer (W70) gave evidence on 23 October 2013 that he saw Duggan reach towards his waist before revealing 'the shape' of a handgun. In a written account made hours after the shooting in August 2011, W70 made no mention of a gun, although in a written statement made three days later he said that he had seen him with a gun. When asked for an explanation, he said that his solicitor had told him to leave mention of the gun out of his account.

54 In the intervening time, there was a series of errors by the police and the IPCC without which the disorders might not have occurred: Bridges (2012).

55 See, in particular, Bridges (2012). See also Guardian/LSE (2011) and Singh et al. (2012). Anger within the black and minority ethnic community (BME) has been fuelled not only by stop and search but also by deaths in police custody (some 200 since 1990) and by the lack of police accountability in any of these matters. For statistics, see INQUEST.

56 See Bridges (2012) who, by way of example, reports statistics showing that in the three months to the end of June 2011, there were 6,894 police stop and searches in the local borough of Haringey, with only $87(1.2 \%)$ of these resulting in an arrest and conviction. The Guardian/LSE survey, Reading the Riots, found widespread complaints of harassment and unjust targeting by the police across the country: Guardian/LSE (2011, Chapter 5). See also, HM Inspectorate of Constabulary (2013a) which goes a long way to confirming the concerns of communities and a substantial body of research over the last fifty years (see further, Chapter 2 infra); and the EHRC Report (2012), which shows (excluding stops under anti-terrorism laws) that overall black people are six times as likely as white people to be stopped but that in some areas the ratio was much higher, as in Thames Valley (10.4 times) and West Midlands (29 times). See also the careful review of evidence in relation 
of legitimacy between the State and the individual in Tottenham (the scene of previous disorders in 1985 also following a police operation that led to the death of Cynthia Jarrett ${ }^{57}$ and an area with a large ethnic minority population which has been the focus of police stop and search and other intrusive powers for many years) and other urban areas to which disorder spread, ${ }^{58}$ by directing blame at a causeless 'hardcore of rioters [who] came from a feral underclass' of whom all '.. were in fact known criminals' ${ }^{59}$

As Ball and Drury (2012) point out, the then Lord Chancellor Kenneth Clarke's term 'hardcore' conveys the notion that 'even if "known criminals" did not make up the numerical majority, they were most instrumental in what happened' (at p. 8). However, Clarke's misleading assertion about the 'hardcore' was to be adopted in spirit days later by the Court of Appeal in $R v$ Blackshaw [2011], a decision which avoided any meaningful examination of the individual circumstances of each appellant, instead relying on an aggregate approach that effectively tarred all with the same judicial brush. In Blackshaw, the appeals by two men who attempted to incite a riot on Facebook were rejected, as were those of five people convicted of burglary, though it reduced the terms of three others for dishonest handling.

By refusing to take acts in isolation, instead preferring to couch their analysis and eventual sentence outcomes in rhetorically forceful but under-articulated terms of 'public protection' and 'interests of justice', the courts subjected defendants to the punitive repercussions of 'the speedy administration of justice' ${ }^{60}$ In doing so, the Court spared itself the task of coming to terms with a more considered analysis of the underlying causes and motivations, including police-community relations.

Bearing in mind that the material cost of the disorders alone was estimated at more than half a billion pounds, ${ }^{61}$ it might be thought that determining the varying causes would be an important measure in 'public protection'. As Lea and Hallsworth (2012) have commented:

to stop and search under section 60, Criminal Justice and Public Order Act 1994 by Shiner (2012).

57 Cynthia Jarrett died from a stroke after being pushed to the floor during a police search operation.

58 After initial targeting of the police, a significant element of general looting and criminal damage took place.

59 Clarke (2011, emphasis added). As Bridges (2012) points out, given that many defendants were identified through subsequent analysis of CCTV images, the arrested population was bound to over-represent those 'known to the police' by reason of previous offences.

${ }^{60} \quad R$ v Blackshaw [2011] at para. 141.

61 Singh et al. (2012). 
... if previous riots had a specific target or grievance - stop and search, competition for jobs - last summer's riots were a diffuse and generalised rage of a dispossessed population angry at a system that has failed them but with no vision of an alternative. This is why they are more serious than any that have gone before. (p. 32)

Instead, what was seen through media accounts of 'frenzied sentencing' was a lack of any proper analysis of the sentencing principles that might reflect the actual level of criminality of individuals, readily abandoned in terms of the immediate management of the 'feral underclass' and manipulation of public opinion. ${ }^{62} \mathrm{~A}$ distinct feature therefore was the rapidity with which large numbers of defendants were processed then subject to a deterrent-led 'uplift' on their sentence.

One strategy for expediting the case-load was for police and prosecutors to circumvent the obstacles of riot - in its legal sense. Rather than charging suspects with the substantive offence of riot, which presents the prosecution with onerous requirements of proof, including the need to evidence unlawful violence for a common purpose, the Ministry of Justice (MoJ) statistics show that the majority of offences brought to court were ones of dishonesty: burglary $(38 \%)$, violent disorder $(27 \%)$, theft $(13 \%)$, robbery $(2 \%)$ and criminal damage $(2 \%){ }^{63}$

In order to further achieve faster processing, working hours at a number of magistrates' courts were extended until the late evening. At two magistrates' courts in central London, the unprecedented step of turning them into night courts was taken in order to deal with the backlog of cases that was forming.

Because of the extended court hours, where 'magistrates' courts sat, literally, through the night to dispose of the work', ${ }^{64}$ defence advocates reported that 'the [prosecution] objected to bail in each and every case suggesting in every instance that the defendant would commit further offences, fail to attend court and interfere with the course of justice'. ${ }^{65}$ Of course, in terms of formal legal rationality, suspects should not have been refused bail on the basis of a general fear of the commission of further offences alone, but on the basis of their particular circumstances. Precise statistics are not available, but practitioners reported that defendants were

\footnotetext{
62 BBC News, 29 August 2011.

63 See MoJ (2011a) at p. 4. Although there were also charges for incitement to riot, notably those cases involving social networking websites.

${ }^{64} \quad R v$ Blackshaw [2011] at para. 141.

65 Young (2011). For severe criticism of one firm of defence solicitors, see $R v$ Ellis (Alexander Tyrone) [2013] in which the Court of Appeal said that the solicitors 'deserve public censure'.
} 
almost routinely remanded into custody ${ }^{66}$ In any event, the deluge of work that coursed through the courts led under-resourced defence lawyers to claim that '[i]t was effectively impossible, in the early hours of the morning, to counter such objections' ${ }^{67}$ It was not only the speed, however, but also the severity of the sanctions that was a distinguishing feature of the crime-control methods in place.

At one stage it was reported that a lay bench in Camberwell Green Magistrates' Court stated that it had been issued with a 'government directive' to jail all riot offenders, raising concerns about the professed independence of the judicial system. In response, the Judicial Office was forced to deny that such a directive had been given although a senior Court Clerk had circulated instructions to court clerks that they should advise magistrates to consider disregarding normal sentencing guidelines. ${ }^{68}$ Indeed, a judge who sentenced offenders at Camberwell Green court made it clear there was an agenda at play when he stated that 'the deterrent sentences sent a very clear signal about the consequences of this sort of offending' ${ }^{69}$

Flying in the face of research which demonstrated the absence of evidence that general deterrent sentences are effective, ${ }^{70}$ the police and court response was united by the strong 'belief' that the visibility of the criminal justice system in action reduced copycat disorder and attrition rates. ${ }^{71}$

This was most noticeably achieved though self-serving 'transparency' from the Government. In what also appears to be an unprecedented measure, the MoJ instructed magistrates' courts nationwide to provide full details of their court outcomes of all riot-related cases. To bolster this strategy, the MoJ and the Home Office made concerted efforts to publish a statistical review of cases which reached the courts, and their progress through the criminal justice system. ${ }^{72}$ For example, in October 2011, the MoJ published an analysis of all cases up to 12 October, ${ }^{73}$ and then followed this up with further analysis of cases up to 1 February 2012. ${ }^{74}$

The research conducted by the Home Office found that there had been over

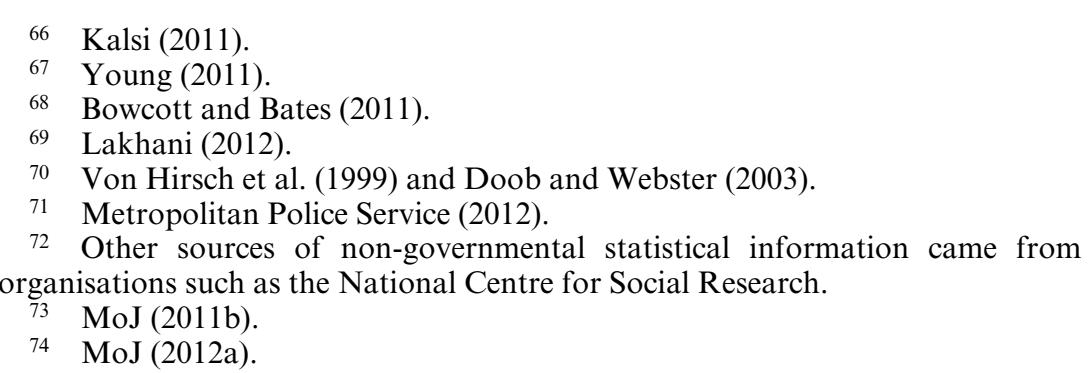


4,000 arrests as a result of the disorders with 5,112 individual related crimes across 10 police force areas. Most were recorded by London's Metropolitan Police, with $68 \%(3,461)$ of the total, followed by Greater Manchester $(11 \%$, 581), West Midlands $(10 \%, 495)$ and Merseyside $(4 \%, 195)$.

Public outrage, fuelled by widespread political and media denunciations, ${ }^{75}$ was soon exacerbated by the deaths of five people and the 200 plus police officers who sustained injuries in the course of tackling the rioters; miscreants whose totality of misbehaviour led to 1,649 burglaries, 141 incidents of disorder and 366 incidents of violence against the person and close to 2,000 incidents of criminal damage and arson. ${ }^{76}$

These statistics were of avail to the courts, allowing them to more easily project the impression that they were 'forced' to deal with an almost unprecedented wave of violent, theft-related and public order cases. Such was the overall scale of the disturbances, that by the time Blackshaw was heard, the Lord Chief Justice of England and Wales remarked that there would 'be very few decent members of our community who are unaware of and were not horrified by the rioting. ${ }^{77}$

The Courts' imperative that there is an 'overwhelming obligation on sentencing courts to do what they can to ensure the protection of the public . . . ${ }^{78}$ was to play an important legitimating role in allowing judges to set aside official sentencing guidelines, give enhanced sentences and discharge them from the rigmarole of an individualised sentencing exercise. In response to this Mitchell $(2011$, p. 5) argues, '[t]he fact that, when aggregated, the total amount of harm done throughout the country was considerable is not per se a good reason for putting such a high priority on protecting the public when sentencing individual offenders'.

Evidently though, feeling the broad support of the public behind them, judges were able to more easily process those implicated in the urban disturbances by exercising their discretion to depart from the Sentencing Council's guidelines on the grounds that it would be contrary to the 'interests of justice' to follow them. On this point, Roberts (2012, p. 440) observed: 'If the enhancement for the riot context was modest, there would be little need to consider how courts go about augmenting sentence severity. However, if the enhancement is considerable, the consequences for principled sentencing are likely to be greater.'

75 Violence, looting and destruction is to be deprecated but the terms in which politicians characterised the disorders were often ill-informed and inflammatory. See, Bridges (2012).

76 HO (2011).

$77 \quad R$ v Blackshaw [2011] at para. 1.

78 Ibid., at para. 4 per Lord Judge. 
In this regard, the Government's own research would indicate a greater need for principled sentencing. An appraisal of the figures produced by the MoJ (up to February 2012) shows the degree to which sentencing enhancements were imposed in response to the urban disorders. ${ }^{79}$ By drawing a comparison between the sentences imposed in the lower courts following the disorders in 2011 with similar offences in 2010, a striking inflationary picture emerges. Taking burglary as an example, the immediate custody rate went from 23 per cent to 42 per cent. The uplift for 'riot-related' theft was more impressive, rising from 2 per cent to 41 per cent. Taking the figures overall, the rate went from 12 per cent to 37 per cent (in other words, more than triple the levels seen in 2010). The length of custody similarly ballooned by more than double (Roberts, 2012). ${ }^{80}$

Indeed subsequent data which looked at those found guilty at the Magistrates' Court but sentenced at the Crown Court, showed stark results. Over 1,400 people received immediate custody with average sentence lengths over four times longer than in 2010: 17.1 months following the disorders compared with 3.7 months in 2010 (Singh et al., 2012) ${ }^{81}$ There are many illustrative cases of severe sentencing for traditionally less serious offences that according to the judges were designed to deter others from similar criminal activity. Some examples include a college student (aged 23) who was sentenced by a District Judge to six months imprisonment for stealing bottled water worth $£ 3.50$ from a looted supermarket in South London; another (aged 19) was jailed for 10 months for stealing two left-footed trainers which she left outside the shop; while one defendant (aged 24) was jailed for 20 weeks for stealing a looted bag of alcohol and sweets he found in the streets. ${ }^{82}$

In the absence of specific directions other than the Sentencing Guidelines, HHJ Gilbart QC, the Recorder of Manchester and vanguard tasked with the first riot case in $R v$ Carter \& Others (16 August 2011) ${ }^{83}$ set out unofficial guidelines for sentencing in the context of August 2011 riots. His comments that the context of riot 'hugely aggravates the seriousness of each

\footnotetext{
79 See Tables 4 and 6 from MoJ (2012a).

80 A similar picture is seen at Crown Court level between 2010 and 2011 with a near tripling (33\% to $85 \%$ ) of the rate of immediate custody. As with the lower courts, custodial lengths doubled $(50 \%)$ with some offences receiving a $110 \%$ increase in sentence length (e.g., criminal damage).

${ }_{81}$ The data also take into account the 'discounts' defendants received for guilty pleas.

82 See also Suleimanov [2013], where the defendant who had not been rioting but pleaded guilty to burglary of a bottle of water and was sentenced to 15 months imprisonment.

83 $R$ v Carter \& Others (Sentencing Remarks) [2011] (16 August 2011).
} 
individual offence' and accordingly allowed departure from Sentencing Guidelines were swiftly adopted by other judges across the country. ${ }^{84}$ Judge Gilbart's starting point (for convictions following a trial) was a high one: 'any adult offender who took part in the events in Manchester/ Salford on the evening of 9 August must expect to lose their liberty for a significant period'. He justified the enhanced sentence ranges by stating that 'these will send a clear and unambiguous message ... which I trust will deter others from engaging in this type of behaviour in the future'. ${ }^{85}$

Delivering sentence on behalf of the court in Blackshaw, Lord Judge crucially endorsed the observations of Judge Gilbart QC, in particular that the nature of disorders took the offences 'completely outside the usual context of criminality'. However, Lord Judge, re-asserting the primacy of the Court of Appeal, set aside the sentence ranges proposed by the Recorder, stating that it was 'inappropriate for Crown Court judges to issue, or to appear to be issuing sentencing guidelines'. While Lord Judge declined to propose any revised starting points himself, the decision reflects the judicial practice of sentencing outside the definitive sentencing guidelines in moments of 'crisis'. In considering the various sentences passed on the offenders, the Court of Appeal was also given an opportunity to comment on the relationship between the offending itself and the overall disorder.

As a preliminary point it can be noted that it is uncontroversial that, as a general principle, an offender who contributes to the harm of a mass riot might merit an enhanced sentence. This is not the same, however, as saying that the individualised nature of sentencing becomes redundant, despite the Courts' efforts to the contrary. As Roberts (2012) has observed, 'the decision to depart should be taken on an individual level, and not because all offending committed during a period of public disorder necessarily and always falls outside the ambit of the existing guidelines' (p. 440). With these disorders, there was a patent need for individualised sentencing because, as the research touched on above amply demonstrates, the crowds involved were heterogeneous and had different incentives and motivations.

Ashworth (2012) cogently argues that the judgment in Blackshaw is significantly flawed by its failure to justify its conclusions on these appeals by reference to the applicable legislation, to relevant guidelines,

84 See, for example, the sentencing remarks of HHJ Chapple in the first case on the riots in London (Inner London Crown Court), $R v$ Alagago \& Ors (25 August 2011); also R. v Twemlow \& Ors (Sentencing Remarks) [2011].

${ }^{85} R v$ Carter \& Others [2011] at 11. 
or to the giving of adequate reasons. For example, Lord Judge, as indicated earlier, said nothing about the appropriate starting points in the judgment. Moreover, while three of the sentences (the handling offences) from the ten cases examined in Blackshaw were halved, there was no indication as to the calculation that was involved, leading Ashworth to observe: '[s]tepping outside a guideline should not mean stepping into an entirely unstructured realm where proper justifications are absent' (2012, p. 95).

Whatever the disorders represented in terms of the tension between individual culpability, socio-economic disadvantage, marginalisation and negative police-community relations, issues that the courts fastidiously avoided, the sentencing practices that sought to punish those caught up in the 'ghastliness' are thus revealed as a model example of the courts seeking to legitimate aggregate justice over individual justice, where the unashamed tendency to overlook mitigation of various kinds was eclipsed by the focus upon under-articulated, court-defined contextual seriousness of the public disorders.

\section{'NORMAL' CASES: COURTS' RESPONSE}

The response of the courts to what they treated as 'abnormal' situations demonstrates why issues of legitimacy must be disentangled from formal legal rationality. Although many of the provisions and procedures relied upon in these situations could be accommodated (with strained interpretation) into the prevailing legal order, routine deviations were regular features. ${ }^{86}$ As Bridges (1975) has pointed out, sanitising such departures was easy in magistrates' courts where formal legal rationality has never been thought necessary by the justice system. Elsewhere, legal cleansing was sought to be secured, not principally through reliance on formal legal rationality (though court decisions sanitised certain police actions) but rather on disparaging characterisations of defendants processed on a group basis, often de-individualised by the media through submergence in a negative social category ('scroungers', 'mobs', 'thugs', 'bullyboys', 'feral'), assisted by a forged consensus with politicians and the media. In

86 The empirical work of Balbus (1973) disclosed similar findings although Balbus himself gave these little recognition in his theoretical model. See Petra Shattuck (1974) who points out that Balbus does not give full recognition to the wholesale departure from the 'norms' that characterise so much of legal and judicial practice (and thereby inadvertently reinforces the image of blind justice and the idealised judicial system). 
these situations, what was thought of as 'rights' turned out to be purely symbolic, with a value not to the individual but to the legitimating fabric of the system.

However much courts struggle to legitimise treatment of defendants at times of social 'crisis', the question arises whether such practices may be applied in 'normal', that is, 'non-crisis' situations, and, if so, how courts seek to rationalise their actions. The issue directly arises in relation to the formalisation of State-induced guilty pleas since this involves replacing in large part a system in which trial is celebrated as the ideal mode of legal rationality with a non-trial process in which State officials are no longer proclaimed to be disinterested parties.

In State-induced guilty pleas, there is no requirement on the prosecution to prove its case by the introduction of admissible and persuasive evidence; there are no restrictions on what might count as 'evidence'; no witnesses are produced to give evidence (indeed, none may be available); there is no independent tribunal of fact; there is no settled procedure under which it should operate (or none that judges and practitioners seem able to follow); and there is no public trial or other independent decision-making tribunal. As the 'fiscal crisis' of the State was invoked in some quarters to openly promote non-trial dispositions, the way in which courts, as State agencies concerned with the appearance of justice and rationality, responded is accordingly a matter of legal and sociological interest.

\section{STATE-INDUCED PLEAS AND THE BOOK PLAN ${ }^{87}$}

Our principal concern in this book is with the responses of the English and Welsh courts in their struggle to preserve a sense of their own legitimacy while engaging with the demands of State-induced guilty pleas. Scotland has been chosen as a useful comparator because although its system of criminal justice is predominantly adversarial and most crimes are common law crimes, ${ }^{88}$ it has traditionally displayed hostility to the idea of State-induced guilty pleas $^{89}$ and it has followed an independent path in the manner in which it addresses the principles and values thereby implicated.

87 For a full exploration of ethical issues involved in the choice between trials and 'plea bargains', see Lippke (2011). See also Bridges (2006).

88 See Leverick (2006) for a detailed account.

89 Following disapproval of sentence discounts in Strawhorn v McLeod [1987], there was 'something of an antipathy towards the practice of sentence discounting in Scotland' (Leverick, 2006, p. 18) and it was not formally operated between the mid-1980s and mid-1990s. 
Nevertheless, and for different reasons, both jurisdictions are now in the grip of State-induced guilty pleas.

In Chapter 2 we examine whether the 'rights' and 'principles' that are said to underlie criminal justice in England and Wales and guarantee the traditional adversary system prevail in non-crisis situations. In Chapter 3 we look at the forces that caused the emergence of State-induced guilty pleas into the public realm in England and Wales and how the courts responded to this in the case of Turner. In Chapter 4 we trace how the deep-seated message of Turner was brought to the surface, sanitised and rationalised by the influential Report of Lord Justice Sir Robin Auld $(2001)^{90}$ in the quest for the proclaimed cost-efficient disposal of criminal cases. Next, we examine the extent to which the State actors and their respective institutions (Chapter 5) and defence lawyers and their institutions (Chapter 6) provide assurance that concerns over State-induced guilty pleas may be properly allayed. Chapter 7 focuses upon Scotland in the practice of negotiations over pleas and the jurisprudential struggle of the courts to rationalise it. Chapter 8 draws out the legal and sociological implications of courts adopting the practice of State-induced guilty pleas and seeking to make it legitimate.

90 We intend no discourtesy to Sir Robin if we refer to him from now on by his surname for convenience. 